\title{
Oracular Sessions and the Installations of Priests and Officials at the Opet Festival
}

\begin{abstract}
Masashi FUKAYA*
The Opet Festival is known for its juridical function relating to the oracles of Amun. There are only three texts unequivocally relevant to its oracular sessions, dated to the Nineteenth Dynasty and later. However, other evidence can be associated with this celebration, based on the dates of events. This paper consists of two parts, each re-examining the known evidence and presenting new one. The new sources examined here are mostly related to the installations of high-ranking individuals, such as the high-priests of Amun, the divine wives, and viziers. Unlike juridical oracular sessions, the dates of their ceremonial appointments are rather peripheral in nature, taking place in proximity either to the beginning or the end of the festival. This may hint at the legal assumption of priestly titles prior to religious events and subsequent approval by the god in ceremonial settings, or reward ceremonies when those individuals received special favours from the king for their devotion to him after particular festivals. The author also notes that the accessions of kings were probably modeled on the same pattern in view that some rulers celebrated an accession anniversary at the Opet Festival in their first regnal year when they went on a tour all over Egypt to proclaim their new authority.
\end{abstract}

Keywords: Opet Festival, oracle, decree, installation, appointment

\section{Introduction}

Clear evidence attesting Egyptian oracular rituals is known only from the New Kingdom onwards. ${ }^{1}$ We have no more than four examples from the Eighteenth Dynasty, all of which pertain to decision-makings on state affairs made by Amun at Thebes. ${ }^{2}$ Two of them are dated - II Peret 30 and III Peret 2. The former is said to have taken place 'at an Amun festival'. According to the Medinet Habu calendar, that day is the second day of Amun's 'Festival-of-Lifting-Up-the-Sky' (MH III, pl. 165, list 60). The latter date also appears to belong to this feast. ${ }^{3}$ It is possible that Amun delivered oracles at many major feasts throughout the year. ${ }^{4}$

\footnotetext{
* D. Phil. candidate in Egyptology, University of Oxford
} 
Theoretically, all the Theban feasts were associated with the supreme god Amun, even though some were celebrated for other gods in the first instance. ${ }^{5}$ Regardless of whether or not Amun was actually involved or not, final oaths as a result of oracular/juridical sessions, were commonly taken in a certain formula beginning with ' $n h$ 'Imn ' $n h$ n-sw.t '(as long as) Amun lives and the king lives!' The association of oracles with secular decision-makings has not yet been fully investigated, but the fact that the decrees of the deified king Amenhotep I could support decisions made by the juridical court, qenbet, suggests a possibility that oracles were closely related to other forms of verdicts, such as royal decrees. ${ }^{6}$ Significantly, a certain proportion of royal decrees were issued at festivals, which shall be discussed in another paper. ${ }^{7}$

Thebes remained a religious centre after the fall of the New Kingdom and some festivals were considered to be the major events of that city until the Ptolemaic Period. The geographical list in the sanctuary of the temple of Edfu, dated to Ptolemy VI, records all the Egyptian nomes as well as their principal towns and local festivals. ${ }^{8}$ For the entry of the Theban nome, four festivals are named: Opet Festival, Khoiak Festival, Festival of I Shemu, and Festival of II Shemu. Of these, the last is likely to be the Festival of the Valley (Klotz 2008, 49 , n. k). ${ }^{9}$ Indeed, the Feasts of Opet and the Valley were regarded as the two most prestigious celebrations in the New Kingdom (Fukaya 2007, 98). They were, for instance, represented in juxtaposition in the reliefs of Hatshepsut's Red Chapel and Deir el-Bahari Temple, and of the Hypostyle Hall at Karnak belonging to Seti I and Ramses II. ${ }^{10}$ Strikingly, we have no evidence attesting an oracular session at the Valley Feast, whereas the Opet Feast is known for its juridical function associated with Amun's oracles.

This paper attempts, first, to re-examine the known evidence of oracular sessions at the Opet Festival. Second, I will present other possible records, hitherto unexplored in the context of this feast, in view that those sessions were associated with the appointments of high officials and priests. This may hopefully contribute to reconstructing the sequence of rituals relating to the bestowal of titles, including the royal accession, at various festivals.

\section{Known evidence of oracular sessions}

There are three unequivocal records attesting oracular sessions at the Opet Feast, all from the Twentieth Dynasty and later, as listed below. They are all juridical in nature and dated to III Akhet, which suggests that oracular sessions took place during the last half of the festival. P Harris records that this festival was celebrated for as long as 27 days in the whole reign of Ramses III (Erichsen 
Oracular Sessions and the Installations of Priests and Officials at the Opet Festival

1933, 21: 2-3). Insofar as this festival is concerned, it appears that Ramses III followed the convention of Ramses II, starting the feast on II Akhet $19 .{ }^{11} \mathrm{He}$ only prolonged the duration of the feast by adding three more days, thus ending on III Akhet 15. II Akhet 19 appears to have remained the initial day of the feast in subsequent times. ${ }^{12}$ Therefore, the present discussion shall be grounded on the assumption that the Opet Feast started on II Akhet 19 and ended in the middle of the next month.

Table 1. Juridical oracular sessions at the Opet Festival

\begin{tabular}{|l|c|c|c|c|}
\hline \multicolumn{1}{|c|}{ Source } & Reign & Year & Date & Remark \\
\hline P BM10335 & Sethnakht & 2 & III Akhet 1 & \\
\hline Stela Cairo JE 91927 & Ramses VI & 7 & III Akhet 8 & in the morning \\
\hline $\begin{array}{l}\text { Text of Djehutymes, } \\
\text { Court IV at Karnak }\end{array}$ & Pinedjem II & $2 ?$ & III Akhet 6? & $\begin{array}{l}\text { at the silver floor } \\
\text { in the morning }\end{array}$ \\
\hline
\end{tabular}

The earliest evidence of oracular session is P BM 10335 dated to year 2 of Sethnakht. ${ }^{13}$ The opening of the text reads:

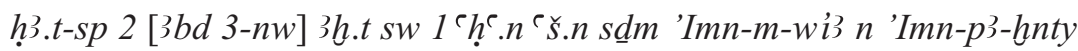
$m$ h $b=f n f r$ h $b$ ip.t $\underline{d} d=f m y[n=i$ 'Imn]- $p 3-[h] n t y$ p $3 y[=i \quad n b]$ nfr $m r$

Year 2, [third month of] Akhet, day 1. The judge Amenemwia appealed to Amun-of-Pakhenty at His Beautiful Festival of the Opet Festival. He said 'come [to me Amun-of]-Pa[khe]nty, [my] good beloved [lord]!'

According to the following story, Amenemwia had previously been robbed of five royal linens. Amun-of-Pakhenty picked out a farmer named Pachauemdiamen from others 'of the entire town' as the thief but he denied the divine decree. Thus, he petitioned to another manifestation of Amun, namely, Amun-of-Tashenyt on an unknown occasion, but ended up receiving the same decree as the first one. For the third time, he came back to Amun-of-Pakhenty at the Khoiak Festival but again the god did not change the initial judgement. Subsequently, he was made to take an oath in front of witnesses that he committed the theft and would return what he had illegally obtained. It is significant that Pachauemdiamen was allowed to have three sessions of divine consultation. 
The stela of Merimaat (Cairo JE 91927) from the time of Ramses VI depicts a bark procession of the Theban Triad in its vignette (Vernus 1975). Towards the bark of Amun-Re is portrayed Merimaat as following a sem-priest. He raises his arms, being assisted by a man. A priest carrying a large container towards another priest is depicted in the lower scene. The main text below the scene reads, as follows:

h3.t-sp [7] 3bd 3-nw (3h.t) sw 8 hr h̆m n-sw.t-bi.ty Nb-m3`.t-re-mry-imn

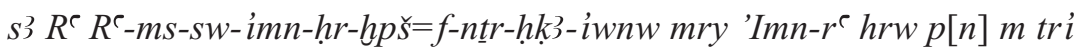

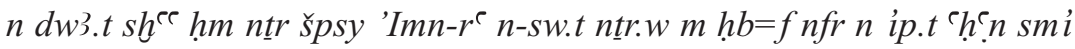

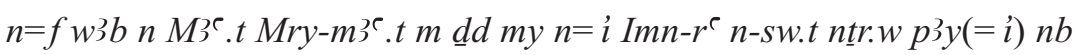

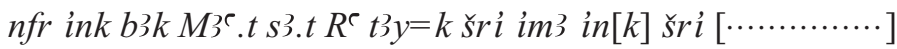

Year [7], third month (of Akhet), day 8 under the person of the king of Upper and Lower Egypt Nebmaatre-meriamen, son of Re Ramsesamenherkhepeshef-netjerheqaiunu, beloved of Amun-Re. On th[is] day in the time of morning, ${ }^{14}$ the majesty of the noble god Amun-Re, king of the gods, appeared at His Beautiful Festival of Opet. The wab-priest of Maat, Merimaat, reported to him by saying 'come to me Amun-Re, king of the gods, (my) good lord! I am the servant of Maat, daughter of Re, your charming girl. I am a child of $[\cdots \cdots \cdots \cdots . \cdots .$.

A representation of an oracular session similar to this is attested on the outer wall at the south-eastern corner of Court IV of Karnak, dated to the time of Pinedjem II. ${ }^{15}$ The wall in question is divided in two parts, in the upper part of which is represented the bark procession of the Theban Triad as moving towards the north. The accompanying text records a petition of a Djehutymes, concerning some evil acts. The text starts from the vertical columns above a thurifying priest, as follows:

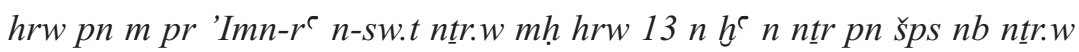
'Imn-re n-sw.t ntr.w Mw.t wr.t nb.t ǐšw Hnsw $m$ w3s.t nfr-ḥtp hr $n$ p3 t3

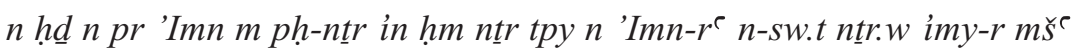
wr ḩ3wty P3-ndm m3e hrw s3 Mn-hpr-re m3e hrw nd dnd hr.w t3 pn m-b3h

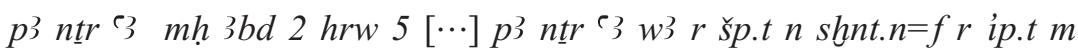

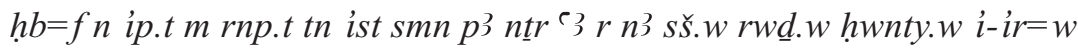

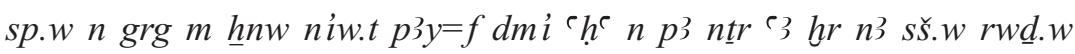

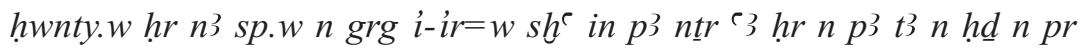

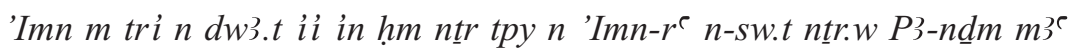


Oracular Sessions and the Installations of Priests and Officials at the Opet Festival

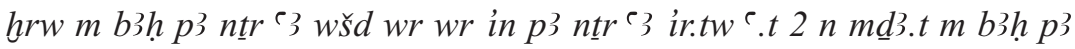

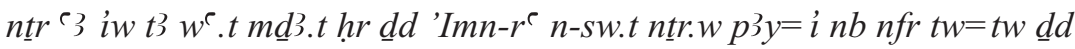
wn md.t iw =tw wh3.t s m-di Dhwty-ms m3 hrw s3 Sw-`.wy-imn m3e

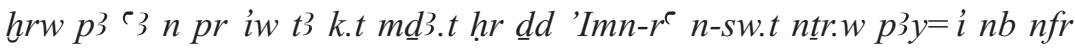

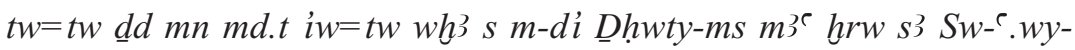

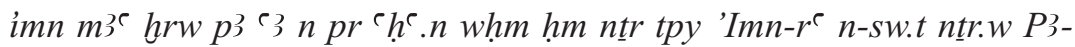

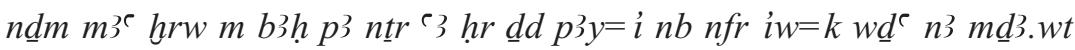
iw $=k$ wd.t $r$ bi3.wt nb.w wšd wr wr in $p 3 n t r$ ?

On this day in the temple of Amun-Re, king of the gods, fourteenth day ${ }^{16}$ of the appearance of this noble god, lord of the gods, Amun-Re, king of the gods, Mut the great, mistress of Isheru, and Khonsu in Thebes, Neferhotep, at the floor of silver in the temple of Amun, in an oracular session ( $p h-n t r)$ by the first prophet of Amun-Re, king of the gods, overseer of the army, general, Pinedjem, true of voice, son of Menkheperre, true of voice, asking about matters of this land in front of the great god. Completing two months and five days (III Akhet $6 ?)^{17}[\cdots]$ the great god, distant from evil. He does not come to Opet ${ }^{18}$ at His Festival of Opet in this year. Now the great god stopped at the scribes, agents, and officers, who did evil acts in the city, his town. The great god condemned ( $h r)$ scribes, agents, and officers for the evil acts that they had done. The great god appeared at the floor of silver in the temple of Amun in the time of morning. The first prophet of Amun-Re, king of the gods, Pinedjem, true of voice, came in front of the great god. The great god responded greatly. Two documents were placed in front of the great god. One document recorded 'Amun-Re, king of the gods, my good lord! One says that there is a matter which one seeks with Djehutymes, true of voice, son of Suauyamen, true of voice, great chamberlain.' The other document recorded 'Amun-Re, king of the gods, my good lord! One says that there is not a matter which one seeks with Djehutymes, true of voice, son of Suauyamen, true of voice, great chamberlain.' The first prophet of Amun-Re, king of the gods, Pinedjem, true of voice, repeated in front of the great god, saying 'My good lord. Will you judge these documents? Will you command every oracle?' The great god responded greatly.

All the evidence presented here reveals that the petitioners are either an official or a low-ranking priest, probably a lay priest. Amun-Re seems to have appeared in a place of more public nature, called the 'floor of silver', where the 
god 'stopped at the scribes, agents, and officers, who did evil acts'. This points to that people were assembled within the Karnak Temple, awaiting the divine procession. To what extent the general public was able to obtain access to oracular rituals is, however, not clear. ${ }^{19}$ It is, at least, certain that commoners could witness the divine processions during festivals when they came out of temple vicinities.

Theoretically, divine decrees could have been issued with full effect after the god underwent all the necessary proceedings at the Luxor Temple, destination of the Opet Feast. The aforementioned text belonging to Djehutymes attests that the Theban Triad appeared at Luxor in II Akhet. Piankhi's stela (Cairo JE 48862) records that the return journey took place on III Akhet $2{ }^{20}$ The Medinet Habu calendar also suggests that the ceremony at Luxor was completed in a relatively short period of time after the beginning of the festival (MH III, pls. 154-6). This calendar gives a detailed description of the first five days in separate lists, followed by three small groups (sixth to eighth, ninth to twentysecond, and twenty-third to twenty-fourth days).

\section{Other evidence relating to the Opet Festival?}

Listed below are texts to be presented here in view that they might be related to the Opet Feast. There are eight in number.

Table 2. Evidence possibly related to the Opet Festival

\begin{tabular}{|l|l|l|l|l|}
\hline \multicolumn{1}{|c|}{ Source } & \multicolumn{1}{|c|}{ Reign } & Year & \multicolumn{1}{|c|}{ Date } & \multicolumn{1}{c|}{ Remark } \\
\hline $\begin{array}{l}\text { Statuette Brussels } \\
\text { Mus E1103 }\end{array}$ & Amenhotep III & 20 & II Akhet & $\begin{array}{l}\text { Nebnefer was appointed a } \\
\text { chief measurer in the granary } \\
\text { of the divine offerings of Amun }\end{array}$ \\
\hline $\begin{array}{l}\text { TT 157 (8) and the } \\
\text { Temple of Seti I at } \\
\text { Abydos }\end{array}$ & Ramses II & 1 & $\begin{array}{l}\text { before III } \\
\text { Akhet 23 }\end{array}$ & $\begin{array}{l}\text { Nebwenenef was appointed the } \\
\text { high-priest of Amun }\end{array}$ \\
\hline O Berlin P 10633 & Ramses III & 29 & II Akhet 23 & $\begin{array}{l}\text { Ta was appointed the vizier of } \\
\text { Upper and Lower Egypt }\end{array}$ \\
\hline $\begin{array}{l}\text { P Bibliothèque } \\
\text { Nationale 237, } \\
\text { Carton 1 }\end{array}$ & Ramses VI & 3 & II Akhet 18 & $\begin{array}{l}\text { oracular session (?) of an } \\
\text { unknown god }\end{array}$ \\
\hline $\begin{array}{l}\text { Court II, Karnak } \\
\text { Khonsu Temple, } \\
\text { Karnak }\end{array}$ & Ramses IX & 10 & III Akhet 19 & $\begin{array}{l}\text { high-priest of Amun } \\
\text { Amenhotep was rewarded }\end{array}$ \\
\hline P Berlin 3048 & Takelot II & 14 & III Akhet 6 & vizier Hori entered Karnak \\
\hline Stela Cairo & Psametik I & 9 & II Akhet 14 & $\begin{array}{l}\text { installation of the divine wife } \\
\text { Nitocris }\end{array}$ \\
\hline
\end{tabular}


It may be desirable to start with Herihor's oracular inscription because it is accompanied by a scene depicting a divine bark, similar to those of Merimaat and Djehutymes. It is carved on the east half of the north wall belonging to the forecourt of the Khonsu Temple at Karank. ${ }^{21}$ The bark of Khonsu carried by priests is represented above the text. Unfortunately, more than half of the text is damaged and the date in the heading is missing. It records an oracular session of Khonsu, pertaining to an honorific appeal by Herihor as the high-priest of Amun-Re, who wished another ten years of priesthood to be added to his twenty years service that Amun-Re had previously granted him. Contrary to the representation, it seems that Amun-Re, not Khonsu, was the god who issued the decree. ${ }^{22}$ After the god's consent ( $h n t p r w r$ wr 'nodding very much'), a passage in line 13 reads:

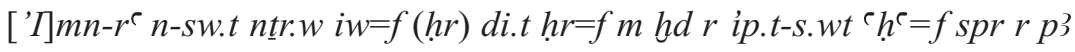
$w b 3[\cdots \cdots \cdots \cdot]$

[A]mun-Re, king of the gods, turned his face northwards to Karnak. Then he arrived at the hall $[\cdots \cdots \cdots \cdot \cdot$.

If this event were part of the Opet Feast, it must have taken place on the return journey to Karnak, probably in III Akhet.

The other seven texts are different in nature from Herihor's appeal. They are dated in proximity either to the beginning or ending of the festival. Nitocris (I) as the eldest daughter of Psametik I was sent to Thebes to become the 'divine wife (hm.t ntr)' of Amun. The Adoption Stela of Nitocris, discovered in the forecourt of Karnak, narrates her voyage up the Nile from the then political centre Sais, taking seventeen days to reach Thebes on II Akhet 14 in year 9 of Psametik I. ${ }^{23}$ The Thebans welcomed her in joy on her arrival at Karnak, followed by the reception rituals, in which Amun received 'what the king made for him', perhaps including his loving daughter Nitocris herself. She was adopted by two incumbent priestesses of Amun, Shepenwepet (II), a daughter of the Nubian ruler Piye, and by Amenirdis (II), a daughter of Taharka.

Nitocris was adopted not directly by the foremost priestess Shepenwepet but by Amenirdis as her eldest daughter, thus becoming the second in line to inherit the office of divine wife. ${ }^{24}$ Yet, the properties possessed by Shepenwepet and Amenirdis were transferred to Nitocris on her very arrival day at Thebes by handing over a property document called imy.t-pr that the parents of Shepenwepet had previously signed for their daughter. ${ }^{25}$ In addition to this, the king donated for Nitocris large new endowments of land in the northern part of 
Upper Egypt and in the Delta. According to Caminos (1964, 99), this seems to have been further authorized with divine approval through an oracular ritual of Amun. When Nitocris disembarked at Karnak on II Akeht 14, it was likely to be some days before the Opet Festival to begin. ${ }^{26}$ Then, she probably officiated as a priestess for the first time at the feast. It should be noted that II Akhet 14 is recorded as the initial day of the Opet Feast in year 23 of Thutmose III. ${ }^{27}$ It is also known elsewhere that the festival started on II Akhet 15 in an unknown year of that king. ${ }^{28}$ It is not impossible that II Akhet 14 was the eve of the feast, as is the case with $\mathrm{P}$ Bibliothèque Nationale 237 below.

Significantly, there are two other instances, in which imy.t-pr is attested in relation to the assumption of high titles. In year 1 of Nebiryaut in the Seventeenth Dynasty, the mayor of El-Kab, Kebsi, sold his office to his relative. ${ }^{29}$ The transfer of the office was insured by an imy.t-pr document on IV Akhet 30. All the witnesses swore on the next day I Peret 1. This indicates that the contract was approved some time later in a ceremonial setting. Indeed, I Peret 1 is elsewhere known as the day of Nehebkau, culmination of the Khoiak Festival starting from the end of IV Akhet. A pattern parallel to this case is attested in the stela of Ahmes-Nefertari, which records her installation as the divine wife of Amun in an unknown year of Ahmes. ${ }^{30}$ A royal decree concerning her appointment was issued in a legal procedure again with an imy.t-pr document on IV Akhet 7, but she was subsequently given the office at the Khoiak Feast.

$\mathrm{P}$ Bibliothèque Nationale 237 might also be related to the installation of a high-ranking person. The papyrus attests a religious event on II Akhet $18 .^{31}$ It is a work journal from Deir el-Medina, dated to year 3 of Ramses VI. Three subjects are recorded on that day: 1) painters and metal workers recorded the king's name in the granary of the Enclosure ( $p 3$ htm $) ; 2)$ the high-priest of Amun (undoubtedly Ramsesnakht) and the royal butler Qedren as well as the overseer of the treasury Mentuemtawy visited Thebes (niw.t); 3) an appearance of an unidentified god $(p 3 n t r)$ and his oracular session associated with an imy.t-pr document, commissioned by the king. ${ }^{32}$ Černý $(1952,29)$ and Borghouts (1982, 25) relate this to an oracular session of the deified king Amenhotep I. On account of the presence of high-ranking individuals, the significance of the event is conspicuous, probably related to the eve of the Opet Feast. ${ }^{33}$ As noted earlier, imy.t-pr is attested in the appointment of the divine wives Nitocris and AhmesNefertari. Thus, it is not impossible that our papyrus records the installation of a high priestess, most probably Isis, a daughter of Ramses VI. However, she is elsewhere known to have assumed the office of the divine wife at the Valley 
Feast. $^{34}$ If she was not the case, the scarcely known vizier Nehy may be considered. He seems to have become a vizier in the time of Ramses VI, succeeding Neferrenpet, who fell in disgrace after year 1 of that king. ${ }^{35}$

We know from many sources that some officials and priests assumed their offices at various festivals. ${ }^{36}$ Among notable figures, Ta and Hori, viziers in the times of Ramses III and Takelot II respectively, might have been installed at the Opet Feast. According to a very short text of O Berlin P 10633, Ta was promoted to the vizier of Upper and Lower Egypt on II Akhet 23 in year 29. ${ }^{37}$ We do not know details as to where he was promoted. However, based on the fact that the ostracon was purchased on the West Bank of Luxor, and that Ta is known to have left Thebes to the north on III Peret 28 in that year after his sojourn in Upper Egypt to collect the gods' statues to celebrate the first Sed Festival of Ramses III at Per-Ramses, the ceremony of his promotion is most likely to have taken place at Thebes. ${ }^{38}$

Likewise, in a short entry in P Berlin 3048, Hori is recorded as entering the Karnak Temple ('k r pr $n$ hm nt tr $n$ 'Imn-r` n-sw.t ntr.w) on III Akhet 6 in year 14 (Jansen-Winkeln 2007, vol. 2, 170). ${ }^{\top} k$ is probably an expression parallel to $s t 3$ and $b s i$, the latter of which was commonly used in relation to the installation of priests in later times (Kruchten 1989, 189).

The proximity of these dates to that of the Opet Feast suggests that Ta and Hori were appointed through Amun's oracles during that festival.

A statue of Nebnefer discovered at the temple of Wadjmes on the West Bank of Luxor records a royal commission concerning the inheritance of an office from his father in year 20 of Amenhotep III. ${ }^{39}$ The text on the back of the statue reads:

[h3.t-sp] 20 3bd 2-nw 3h.t [hr] hm n n-sw.t-bi.ty Nb-m3`.t-re s3 $R^{e}$ 'Imnhtp-hkj3-w3s.t 'nh d.t mry 'Imn $n b$ [ns.wt] t3.wy hnty ip.t-s.wt he.w hr s.t $H r$ n.t 'nh.w mi $R^{\top} r^{\top} n b$ hrw pn ist [hm=f $m$ hw.t-k3-pth $m$ pr] Pth inb-rsy.t=f nb `nh t3.wy wp.t ỉ hr=s šs n-sw.t imy-r pr $H^{\top}-m-p . t n$

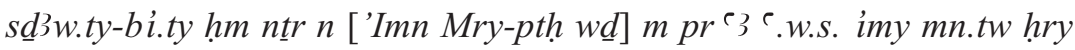

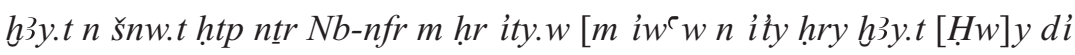
$r$ s.t $=f m$ šnw.t htp ntr $n$ 'Imn

[Year] 20, the second month of Akhet [under] the person of the king of Upper and Lower Egypt, Nebmaatre, son of Re, Amenhotepheqawaset, may he live forever, beloved of Amun, lord of the [thrones] of the Two Lands, foremost of Karnak, appearing on the throne of Horus of the living like Re every day. On this day, now [his person 
was at the House-of-the-Ka-of-Ptah in the temple of] Ptah-South-ofHis-Wall, lord of Life-of-the-Two-Lands. The messenger came concerning it, (namely) the royal scribe, steward, Khaempet, to the seal-bearer of the king of Lower Egypt, high-priest of [Amun, Meryptah. Decree] from the pharaoh, 1.p.h., 'Let the chief measurer of the granary of divine offerings Nebnefer be established before the fathers [as an heir to the father, chief measurer, $\mathrm{Hu}$ ]y, being promoted to his office in the granary of the divine offerings of Amun.'

The following part names some witnesses to his promotion. It appears that Amenhotep III was at Memphis. Thebes is also possible because there was a temple of Ptah to the north of Karnak too. Regardless of where the king was, Nebnefer seems to have been promoted in Thebes because the letter was sent to the high-priest of Amun. The date, however, may refer to the day of the royal decree rather than the day of the assumption of the office. Therefore, whether or not the ceremony took place at the Opet Festival should be left in the realm of conjecture.

Lastly, there are two high-priests of Amun who are likely to have received a special favour from the king at the Opet Feast. Nebwenenef in the time of Ramses II was assigned at or after the Opet Festival. In his tomb at Thebes (TT 157), he is represented as proceeding to the royal couple at the window of appearance. He is followed by fan-bearers and priests, and the accompanying text reads: $:^{40}$

h3.t-sp 1 3bd 3-nw 3h.t $m$-hth hd hm=f $m$ niw.t rsy.t hr ir.t hss.wt ity=f 'Imn-r` nb n-sw.t t3.wy k3 wr hry-tp psd.t Mw.t wr.t nb.t ǐsr Hnsw $m$ w3s.t nfr-ḥtp psd.t imy w3s.t $m$ hb $=$ f nfr $n$ ip.t ỉ im $m$ hs.t [šs]p.tw hs.w

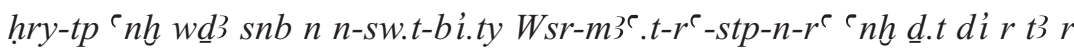

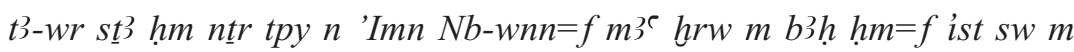
hm ntr tpy $n$ 'In-ḥr $m$ hmm ntr tpy $n$ Hwt-ḥr nb.t iwn.t imy-r hm.w ntr $n$

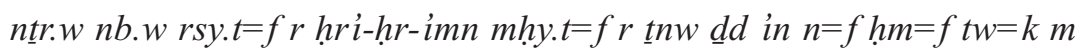
hm ntr tpy n 'Imn

Year 1, the third month of Akhet when his person sailed northwards from the Southern City, having performed what was praised of his father Amun-Re, lord of the thrones of the Two Lands, great bull, foremost of the Ennead, Mut the great, lady of Isheru, Khonsu in Thebes, Neferhotep, and the Ennead in Thebes at His Beautiful Festival of Opet. Returning from there in praise, praises were received 
Oracular Sessions and the Installations of Priests and Officials at the Opet Festival

on behalf of the life, prosperity, and health of the king of Upper and Lower Egypt, Usermaatre-setepenre, may he live forever. Landing at Tawer (Thinis) was made. The high-priest of Amun, Nebwenenef, true of voice, was brought in front of his person. Now he was the highpriest of Onuris, the high-priest of Hathor, lady of Dendara, and the overseer of the priests of all the gods, his south being as far as Heriheramen and his north being as far as Thinis. Then his person said to him: 'You are the high-priest of Amun!'

Fortunately, a more precise date is elsewhere attested relating to this event. According to Ramses II's dedicatory inscription at the temple of Seti I at Abydos, he left Thebes on III Akhet 23 in year 1 and issued a decree to complete that temple. ${ }^{41}$ Thus, the king reached Abydos after that date. The account of Nebwenenef suggests that he traveled with Ramses II in his tour within Upper Egypt in that year. The aim of their journey was to proclaim Ramses II's enthronement as well as his newly established government. It was probably not only Nebwenenef who accompanied the king but also other high officials and priests to be appointed in that year. The formula $s \underline{t} 3 m-b 3 h \underline{h} h m=f$ 'to bring in front of his person' undoubtedly refers to the ceremonial nomination of the priest because the same cliché is applied to describing the installation of the vizier Useramen on the New Year's Day in year 5 of Thutmose III. ${ }^{42}$ It appears that Nebwenenef was installed as the high-priest of Amun at or prior to the travel to Abydos. Is it natural for Nebwenenef to be appointed as the high-priest of Amun at Abydos? Provided that he accompanied the king at Thebes during the Opet Festival, it is more likely that he gained that office at Thebes and was subsequently introduced to the board of the priests of Osiris at Abydos.

The second high-priest of Amun to be mentioned is Amenhotep, who served under Ramses IX and X. On the eastern exterior wall of Court II at Karnak (PM II ${ }^{2}, 172$ (505)), he is depicted as standing in front of Ramses IX and raising his arms with two assistants in a fashion similar to that of Merimaat. The king's speech reads, as follows: ${ }^{43}$

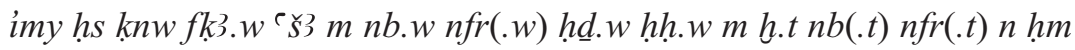

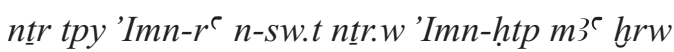

Give many praises and numerous rewards consisting of fine gold and silver, and millions of every good thing to the high-priest of Amun-Re, king of the gods, Amenhotep, true of voice. ${ }^{44}$ 
The following statement says that the rewards were given for the monuments that Amenhotep made at Karnak in the name of the king and the official services in which he was involved. The ceremony took place on III Akhet 19 in year 10 at $w b 3$ ' 3 n'Imn 'great court of Amun', an identical location to what Herihor's inscription mentions, which was perhaps the very place where this relief is carved. Whether or not the ceremony was held at a festival is not specified in the text, but association with the Opet Feast is suggested by the dating. If Ramses IX had still followed the tradition of Ramses III, the ceremony would have taken place after the Opet Festival. Rather close to the ceremony was the 'Amun Festival after the Opet Festival' on III Akhet 17, recorded in the Medinet Habu calendar ( $M H$ III, pl. 158, list 39). Note that this is the earliest known record of Amenhotep as the high-priest, which may suggest his installation on the day in question.

\section{Concluding remark}

Unlike the known records of oracular sessions held in the last half of the Opet Festival, eight sources presented in Section II do not have a juridical context. They bear witness to the installations of high-ranking individuals, except for the case of Herihor. The fact that they took place in Thebes within II Akhet and III Akhet suggests a link to the feast, as evidenced by the example of Nebwenenef, who undoubtedly accompanied Ramses II to celebrate it in year 1. It is significant that the dates available hint at rather peripheral events either at the beginning or the end of the celebration. III Akhet 19, evidenced by the case of Amenhotep, is most likely to have been shortly after the feast. It is possible that all installations were not necessarily be performed in front of Amun, rather the presence of the king sufficed to play a role as a benefactor, acting on behalf of Amun. ${ }^{45}$ Be that as it may, festivals provided a suitable setting to transmit an order of the god through the king to people.

Some questions arise here as to what dates recorded in texts indicate. Are they the days on which those historical figures assumed offices or a decision relating to it was made? As we have seen in some examples involving the imy.t$p r$ documents, the ceremonial installation of priests and officials could take place after the dates recorded, whereas some cases indicate that the king rewarded them after festivals by giving them a higher title or precious materials. We know, for instance, that Amenhotep, son of Hapu, was appointed an administrator after the Sed Festival ( $h f t^{\ulcorner} r k h b s d$ tpy) in year 30 of Amenhotep III. ${ }^{46} \mathrm{He}$ was probably rewarded as such for his life-long devotion to the king. He is known to have died some years later. 
This further leads to another subject as to the interdependence of divine decrees, royal commissions, and reward ceremonies, as well as political situation. In this respect, the accessions of the kings give us an important insight. It is well known that Horemheb celebrated his accession anniversary during the Opet Festival in the first year (Gardiner 1953). ${ }^{47}$ This probably explains Ramses II's sojourn at Thebes in the first year. Seti II is also known to have visited Thebes on II Akhet 10 in year $1 .^{48}$ Ramses III might have also been in Thebes in his year 1. A text at his Medinet Habu Temple says that the king appeared 'at his first Festival of Opet ( $m h b=f$ tpy $n$ ip.t) ${ }^{49}$ According to the Tombos Stela, Thutmose I celebrated his accession anniversary on II Akhet 15 in year 2, while he is elsewhere known to have ascended to the throne on III Peret 21. Spalinger $(1995,278)$ argues that Amenhotep II also celebrated his accession at the Opet Feast, based on the account of Amenemheb (TT 85).$^{50}$ Even after the rulers in the Ramesside Period moved the residential palace to the north, they were in ideal expected to participate this celebration every year, as evidenced by the decree of Horemheb (Pflüger 1946, 263). ${ }^{51}$ It appears, at least, that the kings saw their first regnal year very important and went on an official tour all over Egypt to promulgate the newly established authority. ${ }^{52}$

\section{Notes}

${ }^{1}$ For earlier evidence of oracles before the New Kingdom, see Baines and Parkinson 1998; Kammerzell 2001 for the Old Kingdom, and Anthes 1928, 42, pl. 18; Posener 1963; Blumenthal 1976; Kruchten 2001, 609 for the Middle Kingdom. Oracles concerning non-royal affairs are attested in the Ramesside Period, mostly from Deir el-Medina (Černý 1927 and 1942; Kruchten 2000). Direct material evidence such as speaking statues and related architectural structures are attested in much later times (Loukianoff 1936; Habachi 1947; Brunton 1947; Fakhry 1971), except the doubted pre-dynastic example of a nodding statue of the seated Horus from Hierakonpolis (Simpson 1971, 161, fig. 10). A set of two oracular questionnaires has also been discovered elsewhere (Ryholt 1993; Fischer-Elfert 1996; Kruchten 2000).

2 1) Hatshepsut: the queen visited 'the steps of the lord of the gods' to make a decision on a campaign to Punt (PM II 2347 (14); Urk. IV, 342-3; Shirun-Grumach 1993, 69, 72); 2) Thutmose III: oracular appointment of the young prince Thutmose as a future king when Amun performed a procession within the Hypostyle Hall at Karnak (PM II ${ }^{2}, 106-7$ (328-30); Urk. IV, 158); 3) Thutmose III: Extension-of-the-Cord ritual at Karnak at an Amun festival on II Peret 30 in year 24 when Amun desired to extend the cord himself (Stela Cairo JE 34012; Urk. IV, 8356); 4) Thutmose IV: the king approached Amun at Karnak and asked for a decision on his Nubian campaign on III Peret 2 in year 8 (Konosso inscription; Urk. IV, 1545-8; ShirunGrumach 1993, 80-1).

${ }^{3}$ Although the Medinet Habu calendar records three days duration of the feast from II Peret 29 to III Peret 1, it might have lasted more than three days as the Ptah Feast, as evidenced in P Turin Cat. 1898+1926+1937+2094, dated to III Peret 1 (Botti and Peet 1928, 47, pl. 50; KRI VI, 687: 12) and O DeM 401, dated to III Peret 4 (Černý 1935-70, vol. 5, 17, pl. 16; KRI VI, 125: 8-9).

${ }^{4}$ For Amun's oracles at the New Year Feast, see the north face of the 10th pylon of Karnak (PM $\mathrm{II}^{2}, 187$ (580); Gardiner 1962, 58; Winand 2003, 641; Jansen-Winkeln 2007, vol. 1, 177) and the Banishment Stela (Louvre C 256; von Beckerath 1968, 12; Jansen-Winkeln 2007, vol. 1, 72). 
${ }^{5}$ Amun is known to have appeared to give an oracle at Karnak on I Shemu 10, which coincides with the day of the Feast-of-Clothing-of-Anubis, recorded in the Medinet Habu calendar $(\mathrm{MH}$ III, pl. 167, list 65). On III Shemu 28, Amun appeared again and issued an oracle at the Feast of Ipep, celebrated at Karnak (chapel of Amenhotep II; PM II ${ }^{2}, 186$ (576); KRI VI, 702: 11-3; Nims 1948, 159; Spalinger 1993, 292, n. 11). The calendar of Medinet Habu also records that the Festival of Amun was celebrated on the day when Going-Forth-of-Min-to-the-Stairs took place (MH III, pl. 167, list 67).

${ }^{6}$ For the association of the qenbet sessions with the deified king Amenhotep I, see P Cairo 58092 (P Boulaq X) which records that Amenhotep I gave judgment to a man 'in the qenbet ( $m$ t3 knb.t)' (Janssen and Pestman 1968, 144; McDowell 1990, 128), O Geneva 12550 (McDowell 1990, 113, 256-9), and P DeM 26 (KRI V, 462: 11, 463: 2, 11; Allam 1973, 297-300).

${ }^{7}$ Interdependence between oracles, royal decrees, and secular laws is pointed out in a brief article by Jin $(2001,97-8)$.

${ }^{8}$ PM VI, 146-7 (219-22); Edfou I, 338, XV, pl. 9b; Klotz 2008, 42-3. Spalinger (1992, 14) suspects that these entries may indicate month names, not festivals. In either case, the point of the present discussion does not change because the principal festivals in these months are easily identified.

${ }^{9}$ A geographic list parallel to this is attested from Hieratic papyri discovered at Tebtynis, where the Theban festivals are recorded, as follows: 'II Akhet Amenopet II Shemu Khoiak' (PSI inv. I 2+P Carlsberg 54+P Tebt. Tait Add. 1 a-f+P Berlin 14412i; Osing and Rosati 1998, 33; Osing 1998, 268).

${ }^{10}$ Red Chapel (Lacau and Chevrier 1977-9, registers IV and VI on the south and north exterior walls; Burgos and Larché 2006, vol. 1, 46-53, 60-5, 98-9, 109-14); Deir el-Bahari (PM II ${ }^{2}, 357-$ 8 (79-83); Naville 1985, vol. 5, pls. 122-6); Great Hypostyle Hall of Karnak (PM II ${ }^{2}, 44$ (152, III-1), 46 (157, IV-2-5); 47 (158, III-2); Nelson 1981, pls. 36-40, 53, 151-2).

11 The Medinet Habu calendar records that the festival lasted 24 days from II Akhet 19 to III Akhet 12 ( $M H$ III, pls. 154 and 156, lists 29-35). The discrepancy between Medinet Habu and P Harris is explained by some scholars that Ramses III copied an old festival calendar at the Ramesseum (Nims 1976, 170; Dolińska 2007, 71).

12 Some records from the Roman Period attest this date: P Leiden T 32, III 7-9 (Stricker 1953, 18; Herbin 1994, 151; Klotz 2008, 576; Smith 2009, 413); Esna calendar (PM VI, 113 (15), 114 (24); Sauneron 1963, 125; Grimm 1994, 40-1; El-Sabban 2000, 161); P Boulaq 3, III 22 (=P Louvre 5.158; Sauneron 1952, 10; Klotz 2008, 575-6); Edfu calendar (PM VI, 127 (52), 161 (310); Alliot 1949, 216; Grimm 1994, 40-1; El-Sabban 2000, 174).

13 Blackman 1925; KRI VII, 416-8.

14 The appearance of the god in the morning is attested in other sources: oracular inscription concerning Henuttawy on the north face of the 10th pylon, Karnak (PM II ${ }^{2}, 187$ (580); Gardiner 1962, 58; Winand 2003, 638-9; Jansen-WInkeln 2007, vol. 1, 177); oracular inscription of Djehutymes (below); oracular inscription of Nesamen on the north exterior wall of the chapel of Amenhotep II (PM II², 186 (576); KRI IV, 702: 12; Nims 1948, 159, 1. 13).

$15 \mathrm{PM} \mathrm{II}^{2}, 183$ (553). First published by Naville (1883) and subsequently re-examined by Kruchten (1985 and 1989). Also see Valbelle and Husson 1998, 1061.

${ }^{16} \mathrm{mh} \mathrm{hrw} 13$ (lit. 'completing thirteen days') is likely to indicate the fourteenth day from the beginning of a given event because a parallel expression attested elsewhere does mean the fourth day while it is written hrw mh 3.t (P Louvre 3129; Urk. VI, 143: 17).

${ }^{17}$ While Naville $(1883,4)$ interpreted the date as II Akhet 5 and placed this oracular session before the Opet Feast, Kruchten $(1985,58)$ proposes an unknown event thirteen days before the session and relates the date of the session to II Akhet 19, a widely accepted initial day of the festival. Furthermore, he added 65 days ( 2 months and 5 days) to II Akhet 19, thus regarding IV Akhet 23 as the date of the oracular session in question. It is, however, an anomaly to have an unknown event, which is not mentioned in the text at all (note that there is not space enough to narrate such an event in detail before the extant text). It is more likely that 'completing 65 days' 
means III Akhet 6 from the New Year's Day. Such a means to count days is not widely attested in Egypt but not impossible as a nautical journal in the late Ramesside Period (Ramses IX?) records dates beginning from the first day of the journey at Thebes (P Turin 68; Peet 1930, 482). 'The 14th day' is perhaps referred to as III Akhet 6, which implies that the appearance of the god took place on II Akhet 23. This may explain why our text puts an emphasis on the delay of Amun-Re's arrival at the temple. If the feast were to end on III Akhet 15, as was the case in the reign of Ramses III, more than half the duration of the festival had already elapsed and that would have amounted to an extreme delay of the schedule.

18 Whether Amun here is visiting Luxor or returning to Karnak is unclear. A parallel expression is found in the dedication text of Ramses II at Abydos: hr s3 shn.t 'Imn r ip.t 'after Amun's shn.t to Opet' (PM VI, 3 (34-7); KRI II, 325: 6).

19 Thutmose III's chronicle narrates how he was chosen by Amun as a future king, as follows:

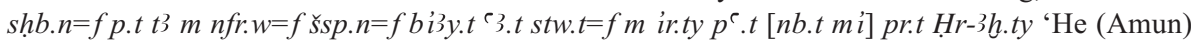
made heaven and land festive with his beauty. He performed a great revelation. His rays were in the eyes of [all] the members of the pat [like] the coming-forth of Horakhety' (Urk. IV, 157-8). At this oracular session only certain privileged individuals (pat) witnessed the divine appearance in the Hypostyle Hall at Karnak. In a similar fashion, Horemheb in his accession text narrated how he was selected by Amun but with extended audiences, as follows: stny $s 3=f$ $m$ hr t3 tm.w '(Amun) distinguished his son in front of the entire land'. As a designation of population the pat is construed to refer to an elite component of the society, whereas its counterpart rhy.t is generally understood as the common folk. Bell (1997, 164-7) demonstrated on account of the distribution of the rhy.t signs within the forecourt of the Luxor Temple that the folk could enter the eastern half of the court while the divine processions took place in the western half.

${ }^{20}$ Urk. III, 15: 3; Grimal 1981, 15*; Jansen-Winkeln 2007, vol. 2, 341.

${ }^{21} \mathrm{PM} \mathrm{II}^{2}, 231$ (22, III-2); Khonsu II, 14- 7, pl. 132.

${ }^{22}$ A joint session with Khonsu is evidenced by another oracular inscription of the high-priest of Amun Menkheperre, located in the same court (PM II², 231 (22); Khonsu II, 14-7, pl. 132).

23 Stela Cairo JE 36327 (PM II², 27; Caminos 1964, 74).

${ }^{24}$ According to Dodson (2002, 181-2), when Amenirdis adopted Nitocris as her successorin to the college of Amun, the former came to gain the new title 'divine hand' (dr.t-ntrr). She, however, remained in this position while Nitocris successfully ascended from divine adoratice to divine wife.

25 Caminos 1964, 75, 11. 16, 86. The imy.t-pr was not only a secular legal document but was also related to divine decrees, as depicted in a relief at the Hypostyle Hall of Karnak, where Thoth is represented as writing it for the king (Nelson 1981, pl. 96). For general discussion on this document, see van den Boorn 1988, 180-1 and Logan 2000.

26 When Psametik II, a grandson of Psametik I, succeeded his father Necho II, he sent his daughter Ankhnesneferibre to Nitocris in Thebes on III Shemu 29 in year 1. Serving her office as long as over sixty years, Nitocris was old enough and perhaps ready to have an heiress from Sais. The stela of Ankhnesneferibre discovered in Court I of Karnak records that Nitocris, then in the highest office of divine wife of Amun, inducted Ankhnesneferibre to Amun in order to bestow on her new titles including 'the high priest of Amun' (Stela Cairo JE 36907; PM II ${ }^{2}$, 166; Leahy 1996). Ten years later in year 4 of Apries, Nitocris died after enjoying her considerable life longevity. Subsequently, Ankhnesneferibre was appointed the 'divine wife' and 'divine adoratice' in ceremonies at Karnak and all the temple personnel gathered for this occasion on IV Shemu 16, which was twelve days after Nitocris' death. What looks like a legal procedure with the need of documentation (1. 11, nt- ${ }^{\top} . w n b n$ bsi $d w 3 . t$ ntr $n$ 'Imn 'every document of the induction of the divine adoratice of Amun') occurred at this time, not at the time when Ankhnesneferibre arrived at Karnak for the first time. Back to Ankhnesneferibre's first initiation ritual on III Shemu 29, it perhaps took place at the Ipet Festival, during which the concentration of some religious events is observed at the turn of III Shemu and IV Shemu. Despite the 
designation of the festival, there is not much evidence relating to the hippopotamus goddess Ipet (or Ipep) in the context of her festival, but rather Amun-Re seems to have played a central role. In one text from the time of Ramses XI, an oracular session of Amun-Re is recorded as taking place at the Ipet Feast (chapel of Amenhotep II, Karnak; PM II ${ }^{2}, 186$ (576); KRI VI, 702: 11-3). Thus, it is likely to have been a suitable event for Ankhnesneferibre, accompanied by the highest priestess, to assume an office of great importance under the authority of Amun. On the other hand, her second initiation ritual on IV Shemu 16 was probably organized hastily soon after the death of Nitocris, and no religious event is elsewhere known around this date.

27 6th pylon at Karnak (PM II ${ }^{2}, 90$ (245); Urk. IV, 742: 1).

${ }^{28}$ Stone block of a festival list from Elephantine (LD III, pl. 43 c; Urk. IV, 824: 10).

29 Juridical Stela (Cairo JE 52453; PM II², 52; Helck 1975, 65-9; Logan 2000, 60-3).

${ }^{30}$ Unnumbered stela (PM II², 73; Harari 1959; Gitton 1975, 6-11; Logan 2000, 63-4).

${ }^{31} \mathrm{P}$ Bibliothèque Nationale 237, Carton 1 (KRI VI, 339: 13; Černý, Notebook, no. 46, 2). I Akhet 18 in the original text is to be amended to II Akhet 18 because the text starts with another date II Akhet 14 .

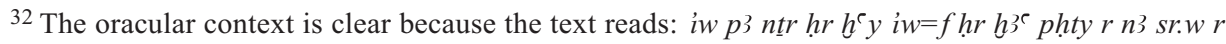

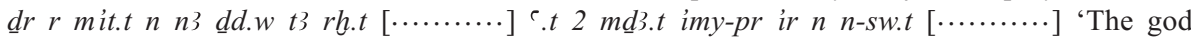
appeared. He turned the back to all the dignitaries in accordance with what the wise woman said $[\cdots \cdots \cdots \cdots]$ two pieces of a property document made by the king $[\cdots \cdots \cdots \cdots \cdot . \cdot$.' An expression similar to this $p n^{`}=f r r m \underline{t}$ 'he turnded to/againt people' is attested in the oracular text Herihor presented above (Khonsu II, 17, 1. 11).

33 The eve of the Opet Feast is recorded in the Medinet Habu calendar as taking place on II Akhet 18 ( $M H$ III, 154, list 28).

${ }^{34}$ Relief fragments from Deir el-Bakhit in West Thebes, now lost (LD III, pl. 218 a-b, better in text III, 101; KRI VI, 321-2). For this controversial monuments, see Černý (1958, 32), Seele (1960, 195), and Kitchen $(1972,190)$. Seele, in particular, suggested a possibility that there were two women of the identical name Isis, having the same title of the divine wife. For new materials relating to Isis, see Rummel 2011.

${ }^{35}$ Lintel Pennsylvania 13567 (Ranke 1950, 100; Helck 1958, 464 (22)) and O KV 18/6.924+O Cairo 25726+O BM 50722 (KRI VI, 364: 4; Dorn 2011, 160).

36 Installation of the vizier Useramen on the New Year's Day in year 5 of Thutmose III, attested in P Turin 1878 (Urk. IV, 1384: 3; Dziobek 1998, 98). This episode is also illustrated in his tomb (TT 131 (8); Urk. IV, 1380-3; Dziobek 1994, pls. 72, 81). Installation of two priests at the Luxor Temple on the second Epagomenal day, dated to year 3 of Tanutamen (built-in blocks in south exterior wall, now known as Berlin 2096 and 2097; PM II ${ }^{2}$, 335-6 (223); Vittmann 2001; Jansen-Winkeln 2009, 245-7). Many priests were appointed at Karnak during the Feast of I Shemu in the Twenty-First to Twenty-Third Dynasties (Kruchten 1989).

${ }^{37} \mathrm{KRI}$ V, 530: 1-2. According to Wolterman (1996, 164), he had previously been the northern vizier, at latest, from year 16 , opposed by Peden $(2000,14)$ who is inclined to the idea of the southern vizier.

38 P Turin 1880 (Gardiner 1948, 45-8; Allam 1973, 310-2). Elsewhere Ta is also recorded to have visited El-Kab to fetch the divine barge of Nekhbet for the Sed Festival (Gardiner 1910).

${ }^{39}$ Statuette Brussels Mus E1 103 (PM II ${ }^{2}$, 444; Urk. IV, 1885-6; O’Connor and Cline 1998, 15, n. 72).

40 PM I-I², 267 (8); Sethe 1907, 30-1; Frood 2007, 35-9. For other recent publications, see Spalinger 2009, 28, n. 75 .

41 PM VI, 3 (34-7); KRI II, 325: 5-6; Gauthier 1910, 55; Spalinger 2009, 22.

42 See note 36 above.

${ }^{43}$ KRI VI, 455-7; Frood 2007, 68-72.

${ }^{44} h s$ and $f k 3$ are also attested together in the aforementioned dedication text of Ramses II at Abydos, where the king is described as receiving them from Amun at the Opet Festival (KRI II, 325: 6-7). 
Oracular Sessions and the Installations of Priests and Officials at the Opet Festival

${ }^{45}$ Wolterman $(1996,161)$ posits that viziers were customarily installed not by oracles of Amun but by royal commissions.

${ }^{46}$ Painted stone block discovered at his temple on the West Bank of Thebes (PM II ${ }^{2}, 455$; Urk. IV, 1837: 9; Robichon and Varille 1936, vol. 1, pl. 35; Parker 1950, 61).

47 The co-celebration of two different feasts is attested in the time of Ramses III, who held the first Sed Jubilee as the Feast of Tatenen, probably at Memphis (P Harris I, 49: 10; Erichsen 1993, 56).

48 O Cairo 25560 (KRI IV, 302: 2-3; Černý 1935, 45*, pl. 29).

49 PM II², 495 (77 c); $M H$ IV, pl. 237 A.

${ }^{50}$ Urk. IV 897: 1-4; PM I-12 172 (17).

${ }^{51}$ In the chronicle of Osorkon (III), son of Takelot II, he is said to have visited Thebes three times a year, perhaps including a journey to participate the Opet Feast (Caminos 1958, 78, 117-8).

${ }^{52}$ In P Harris I, 76: 2 (Erichsen 1933, 92), Ramses III is recorded as having ascended to the throne, being crowned by Amun-Re, Re-Atum, and Ptah. This may suggest that the king celebrated his accession at the major cities, Thebes, Heliopolis, and Memphis.

\section{References}

Allam, S. 1973: Hieratische Ostraka und Papyri aus der Ramessidenzeit, 2 vols., Tübingen.

Alliot, M. M. 1949: Le culte d'Horus à Edfou au temps des Ptolémées, Cairo.

Anthes, R., and G. Möller 1928: Die Felseninschriften von Hatnub, nach den Aufnahmen Georg Möllers, Leipzig.

Baines, J., and R. Parkinson 1998: “An Old Kingdom Record of an Oracle? Sinai Inscription 13,” in J. V. Dijk (ed.), Essays on Ancient Egypt in Honour of Herman te Velde, Groningen, 9-27.

Bell, L. 1997: “The New Kingdom Divine Temple: the Example of Luxor,” in B. E. Shafer (ed.), Temples of Ancient Egypt, Ithaca, 127-84.

Blackman, A. M. 1925: "Oracles in Ancient Egypt I," Journal of Egyptian Archaeology 11, 249 55.

Blumenthal, E. 1976: "Die Datierung der Nhrî-Grafiiti von Hatnub," Altorientalische Forschungen 4, 35-62.

Borghouts, J. F. 1982: “Divine Intervention in Ancient Egypt and Its Manifestation (b3w)," in R. J. Demarée and J. J. Janssen (eds.), Gleanings from Deir el-Medîna, Leiden, 1-70.

Botti, G., and E. T. Peet 1928: Il giornale della necropoli de Tebe, Torino.

Brunton, G. 1947: "The oracle of Kôm el-Wist," Annales du Service des Antiquités de l'Egypte 47, 293-5.

Burgos, F., and F. Larché 2006: La chapelle rouge: le sanctuaire de barque d'Hatshepsout, 2 vols., Paris.

Caminos, R. A. 1958: The Chronicle of Prince Osorkon, Rome.

Caminos, R. A. 1964: “The Nitocris Adoption Stela," Journal of Egyptian Archaeology 50, 71 100.

Černý, J. 1927: “Le culte d'Amenophis Ier chez les ouvriers de la nécropole Thébaine,” Bulletin de l'Institut Français d'Archéologie Orientale 27, 159-97.

Černý, J. 1935: Ostraca hiératiques: nos. 25501-25832, 2 vols., Cairo.

Černý, J. 1935-70: Catalogue des ostraca hiératiques non littéraires de Deir el Médineh, 8 vols., Cairo.

Černý, J. 1942: "Nouvelle série des questions adressées aux oracles," Bulletin de l'Institut Français d'Archéologie Orientale 41, 13-24.

Černý, J. 1952: Paper and Books in Ancient Egypt: An Inaugural Lecture Delivered at University College, London, 29 May, 1947, London. 
Černý. J. 1958: "Queen Ēse of the Twentieth Dynasty and Her Mother," Journal of Egyptian Archaeology 44, 31-7.

Chassinat, É. 1897: Le temple d'Edfou, Paris.

Dodson, A. 2002: "The Problem of Amenirdis II and the Heirs to the Office of God's Wife of Amun during the Twenty-Sixth Dynasty," Journal of Egyptian Archaeology 88, 179-86.

Dolińska, M. 2007: "Temples at Deir el-Bahari in the New Kingdom," in 6. Ägyptologische Tempeltagung: Funktion und Gebrauch altägyptischer Tempelräume: Leiden, 4.-7. September 2002, Wiesbaden, 67-82.

Dorn, A. 2011: "The Provenance and Context of the Accession Ostracon of Ramesses VI," in Ramesside Studies in Honour of K. A. Kitchen, Bolton, 159-68.

Dziobek, E. 1994: Die Gräber des Vezirs User-Amun: Theben Nr. 61 und 131, Mainz.

Dziobek, E. 1998: Denkmäler des Vezirs User-Amun, Heidelberg.

El-Sabban, S. 2000: Temple Festival Calendars of Ancient Egypt, Liverpool.

Epigraphic Survey 1934: Medinet Habu III: the Calendar, the "Slaughter House", and Minor Records of Ramses III, OIP 23, Chicago.

Epigraphic Survey 1940: Medinet Habu IV: Festival Scenes of Ramses III, OIP 51, Chicago.

Epigraphic Survey 1981: The Temple of Khonsu II: Scenes and Inscriptions in the Court and the First Hypostyle Hall, OIP 103, Chicago.

Erichsen, W. 1933: Papyrus Harris I: hieroglyphische Transkription, Bruxelles.

Fakhry, A. 1971: "Recent Excavation at the Temple of the Oracle at Siwa Oasis" in Aufsätze zum 70. Geburtstag von Herbert Ricke, Wiesbaden, 17-33.

Fischer-Elfert, H. W. 1996: "Two Oracle Petitions Addressed to Horus-Khau with Some Notes on the Oracular Amuletic Decrees," Journal of Egyptian Archaeology 82, 129-44.

Frood, E. 2007: Biographical Texts from Ramessid Egypt, Atlanta.

Fukaya, M. 2007: "Distribution of Life Force in the Festival of the Valley: A Comparative Study with the Opet Festival," Orient 42, 95-124.

Gardiner, A. H. 1910: "The Goddess Nekhbet at the Jubilee Festival of Rameses III," Zeitschrift für Ägyptische Sprache und Altertumskunde 48, 47-51.

Gardiner, A. H. 1948: Ramesside Administrative Documents, London.

Gardiner, A. H. 1953: "The Coronation of King Haremhab," Journal of Egyptian Archaeology 39, 13-31.

Gardiner, A. H. 1962: "The Gods of Thebes as Guarantors of Personal Property," Journal of Egyptian Archaeology 48, 57-69.

Gauthier, H. M. 1910: "La grande inscription dédicatoire d'Abydos," Zeitschrift für Ägyptische Sprache und Altertumskunde 48, 52-66.

Gitton, M. 1975: L'épouse du dieu, Ahmes Néfertary: documents sur sa vie et son culte posthume, Paris.

Grimal, N.-C. 1981: La stèle triomphale de Pi('ankh)y au Musée du Caire, JE 48862 et 4708647089, Cairo.

Grimm, A. 1994: Die altägyptischen Festkalender in den Tempeln der griechisch-römischen Epoche, Wiesbaden.

Habachi, L. 1947: "Finds at Kôm el-Wist," Annales du Service des Antiquités de l'Egypte 47, 2857.

Harari, I. 1959: "Nature de la stèle de donation de fonction du roi Ahmôsis à la reine AhmèsNefertari," Annales du Service des Antiquités de l'Egypte 56, 139-201.

Helck, W. 1958: Zur Verwaltung des Mittleren und Neuen Reichs, Leiden. 
Helck, W. 1975: Historisch-biographische Texte der 2. Zwischenzeit und neue Texte der 18. Dynastie, Wiesbaden.

Herbin, F. R. 1994: Le livre de parcourir l'éternité, Leuven.

Jansen-Winkeln, K. 2007: Inschriften der Spätzeit, Wiesbaden.

Helck, W. 2009: Inschriften der Spätzeit, Teil III: Die 25. Dynastie Wiesbaden.

Janssen, J. J., and P. W. Pestman 1968: "Burial and Inheritance in the Community of the Necropolis Workmen at Thebes," Journal of the Economic and Social History of the Orient 11, 137-70.

Jin, S. 2001: "Ein Gottesurteil im p.Boulaq X: Ein Fall von "Balance of Power" bei dem Gottesorakel?," Journal of the Economic and Social History of the Orient 44, 95-102.

Kammerzell, F. 2001: ““... Within the Alter of the Sun' - an Unidentified Hieroglyph and the Construction of the Sun Temple nhn-r'w," Lingua Aegyptia 9, 153-64.

Kitchen, K. A. 1972: "Ramesses VII and the Twentieth Dynasty," Journal of Egyptian Archaeology 58, 182-94.

Kitchen, K. A. 1975-90: Ramesside Inscriptions: Historical and Biographical, 8 vols., Oxford.

Klotz, D. 2008: "Kneph: the Religion of Roman Thebes," Thesis (Ph. D.), Yale University.

Kruchten, J.-M. 1985: "Un instrument politique original: « La belle fête de $p h \underline{h-n t r}$ » des roispretres de la XXI Dynastie,” Bulletin de la Société Française d'Egyptologie 103, 6-26.

Kruchten, J.-M. 1989: Les annales des prêtres de Karnak (XXI-XXIIImes Dynasties) et autres textes contemporains relatifs à l'initiation des prêtres d'Amon, Leuven.

Kruchten, J.-M. 2000: "Un oracle d'Amenhotep du village sous Ramsès III: Ostracon Gardiner 103," in R. J. Demarée and A. Egberts (eds.), Deir el-Medina in the Third Millennium AD: A Tribute to Jac. J. Janssen, Leiden, 209-16.

Kruchten, J.-M. 2001: “Oracles,” in D. B. Redford (ed.), The Oxford Encyclopedia of Ancient Egypt, vol. 2, Oxford, 609-12.

Lacau, P., and H. Chevrier 1977-9: Une chapelle d'Hatshepsout à Karnak, 2 vols., Cairo.

Leahy, A. 1996: “The Adoption of Ankhnesneferibre at Karnak," Journal of Egyptian Archaeology $82,145-65$.

Lepsius, R. 1849-59: Denkmaeler aus Aegypten und Aethiopien: nach den Zeichnungen der von Seiner Majestaet dem Koenige von Preussen Friedrich Wilhelm IV nach diesen Laendern gesendeten und in den Jahren 1842-1845 ausgefuehrten wissenschaftichen Expedition, 12 vols., Berlin.

Logan, T. 2000: “The jmyt-pr Document: Form, Function, and Significance," Journal of American Research Center in Egypt 37, 49-73.

Loukianoff, G. 1936: "Une statue parlante ou oracle du dieu Ré-Harmakhis," Annales du Service des Antiquités de l'Egypte 36, 187-93.

McDowell, A. G. 1990: Jurisdiction in the Workmen's Community of Deir el-Medina, Leiden.

Naville, É. H. 1883: Inscription historique de Pinodjem III, grand prêtre d'Ammon à Thèbes, Paris.

Naville, É. H. 1895: The Temple of Deir el Bahari, 6 vols., London.

Nelson, H. H. 1981: The Great Hypostyle Hall at Karnak, OIP 106, Chicago.

Nims, C. F. 1948: "An Oracle Dated in 'the Repeating of Births," Journal of Near Eastern Studies 7, 157-62.

Naville, É. H. 1976: "Ramesseum Sources of Medinet Habu Reliefs," in Studies in Honor of George R. Hughes, Chicago, 169-75.

O’Connor, D. B., and E. H. Cline 1998: Amenhotep III: Perspectives on His Reign, Ann Arbor.

Osing, J. 1998: Hieratische papyri aus Tebtunis I, 2 vols., Copenhagen. 
Osing, J., and G. Rosati 1998: Papiri geroglifici e ieratici da Tebtynis, Firenze.

Parker, R. A. 1950: The Calendars of Ancient Egypt, Chicago.

Peden, A. J. 2000: "Carter Graffito No. 1450 and the Last Known Attestation of the Vizier To in Year 32 of Ramesses III,” Göttinger Miszellen 175, 13-5.

Peet, E. T. 1930: “An Ancient Egyptian Ship's Log,” Bulletin de l'Institut Français d'Archéologie Orientale 30, 481-90.

Pflüger, K. 1946: “The Edict of King Horemhab," Journal of Near Eastern Studies 5, 260-76.

Porter, B., and R. L. B. Moss 1960: Topographical Bibliography of Ancient Egyptian Hieroglyphic Texts, Reliefs, and Paintings I: The Theban Necropolis 1: Private Tombs, Second edition, Oxford.

Porter, B., and R. L. B. Moss 1970: Topographical Bibliography of Ancient Egyptian Hieroglyphic Texts, Reliefs, and Paintings VI: Upper Egypt, Chief Temples, Oxford.

Porter, B., and R. L. B. Moss 1972: Topographical Bibliography of Ancient Egyptian Hieroglyphic Texts, Reliefs, and Paintings II: Theban Temples, Second edition, Oxford.

Posener, G. 1963: “Aménémopé 21, 13 et bj3j.t au sens d'" oracle »," Zeitschrift für Ägyptische Sprache und Altertumskunde 90, 98-102.

Ranke, H. 1950: The Egyptian Collections of the University Museum, Philadelphia.

Robichon, C., and A. Varille 1936: Le temple du scribe royal Amenhotep, fils de Hapou, Cairo.

Rummel, U. 2011: “Two Re-used Blocks of the God's Wife Isis at Deir el-Bakhit/Dra' Abu elNaga (western Thebes)," in Ramesside Studies in Honour of K. A. Kitchen, Bolton, 423-31.

Ryholt, K. S. B. 1993: “A Pair of Oracle Petitions Addressed to Horus-of-the-Camp,” Journal of Egyptian Archaeology 79, 189-98.

Sauneron, S. 1952: Rituel de l'embaumement: Pap. Boulaq III, Pap. Louvre 5.158, Cairo.

Sauneron, S., and L Ménassa 1963: Le temple d'Esna, Cairo.

Seele, K. C. 1960: "Ramesses VI and the Medinet Habu Procession of the Princes," Journal of Near Eastern Studies 19, 184-204.

Sethe, K., and W Helck 1906-58: Urkunden der 18. Dynastie: Übersetzungzu den Heften 1-22, Leipzig, Berlin.

Shirun-Grumach, I. 1993: Offenbarung, Orakel und Königsnovelle, Wiesbaden.

Simpson, W. K. 1971: “A Hours-of-Nekhen Statue of Amenhotpe III from Soleb,” Boston Museum Bulletin 69, 152-63.

Smith, M. 2009: Traversing Eternity: Texts for the Afterlife from Ptolemaic and Roman Egypt, Oxford.

Spalinger, A. J. 1992: Three Studies on Egyptian Feasts and Their Chronological Implications, Baltimore.

Spalinger, A. J. 1993: “A Chronological Analysis of the Feast of thy," Studien zur Altägyptischen Kultur 20, 289-303.

Spalinger, A. J. 1995: "The Calendrical Importance of the Tombos Stela," Studien zur Altägyptischen Kultur 22, 271-81.

Spalinger, A. J. 2009: The Great Dedicatory Inscription of Ramesses II: A Solar-Osirian Tractate at Abydos, Leiden, Boston.

Stricker, B. H. 1953: "De egyptische mysterien Pap. Leiden T 32," Oudheidkundige Mededeelingen uit het Rijksmuseum van Oudheden te Leiden 34, 13-31.

Valbelle, D., and G. Husson 1998: "Les questions oraculaires d’Égypte: histoire de la recherche, nouveautés et perspectives," in W. Clarysse, A. Schoors, and H. Willems (eds.), Egyptian Religion: the Last Thousand Years: Studies Dedicated to the Memory of Jan Quaegebeur, Leuven. 
Oracular Sessions and the Installations of Priests and Officials at the Opet Festival

Van den Boorn, G. P. F. 1988: The Duties of the Vizier: Civil Administration in the Early New Kingdom, London.

Vernus, P. 1975: "Une texte oraculaire de Ramsès VI," Bulletin de l'Institut Français d'Archéologie Orientale 75, 103-10.

Vittmann, G. 2001: "Zwei Priestereinführungsinschriften der 25. Dynastie aus Luxor (Berlin 2096 und 2097)," Studien zur Altägyptischen Kultur 29, 357-70.

Von Beckerath, J. 1968: "Die 'Stele der Verbannten' im Museum des Louvre" Revue d'Égyptologie 20, 7-36.

Winand, J. 2003: "Les décrets oraculaires pris en l'honneur d'Henouttaouy et de Maâtkarê (Xe et VIIe pylônes)," in Cahiers de Karnak XI, Cairo, 603-710.

Wolterman, C. 1996: "A Vizier of Ramses III Visits an Oracle of Amun and Deir el-Medina," Revue d'Égyptologie 47, 147-70. 
